\title{
Endodontic treatment of immature tooth - a challenge
}

\author{
Sonu Gupta ${ }^{1, A-D \oplus}$, Surender Pal Singh Sodhi ${ }^{1, E \oplus}$, Gursimrat Kaur Brar ${ }^{1, D \oplus}$, \\ Ravinder Nath Bansal2,B,D $\odot$ \\ ${ }^{1}$ Dasmesh Institute of Research \& Dental Sciences, Faridkot, India \\ ${ }^{2}$ Guru Gobind Singh Medical Hospital, Faridkot, India \\ A - Research concept and design, B - Collection and/or assembly of data, C - Data analysis and interpretation, \\ $D$ - Writing the article, E - Critical revision of the article, F - Final approval of article
}

Sonu Gupta, Surender Pal Singh Sodhi, Gursimrat Kaur Brar, Ravinder Nath Bansal. Endontic treatment of immature tooth - a challenge. J Pre Clin Clin Res. 2020; 14(3): 73-79. doi: 10.26444/jpccr/126280

\begin{abstract}
Root apex is an area of primary importance for an endodontist. When a tooth erupts in the oral cavity the apical foramen undergoes anatomical changes with age. Root development is completed and the root apex is closed three years after eruption of the tooth. Endodontic practice is influenced to a great extent by different stages of root development and the type of tissue present within the roots. Open apices pose a challenging problem for the success of root canal treatment because they favour the extravasation of the irrigating solution and/or sealer into periradicular tissues, thus jeopardizing apical healing. Regenerative endodontics (revascularization/pulpal regeneration) is a straightforward approach accomplished with currently available instruments and materials. A literature review suggests that Mineral Tri oxide Aggregate (MTA) is the most favourable and recommendable material for single-visit apexification, even in cases when regenerative endodontics cannot be performed. A plus point of MTA is its biocompatibility and hermetic apical seal with no micro-leakage. It should be considered as an effective alternate for treating immature teeth with necrotic pulps. Treatment of a tooth with open apex poses multiple challenges. However, it is not easy to decide which material should be used: Calcium hydroxide, Mineral Tri oxide Aggregate, Biodentine, Platlet Rich Fibrin (PRF), or White Portland Cement (WPC). The choice of treatment regimen depends on several factors, e.g. individual cases, experience of the operator, familiarity with handling various materials, and patient's availability for follow-up appointments. This review highlights various challenges in the treatment of open apex, with emphasis on MTA compared with other materials.
\end{abstract}

\section{Key words}

immature tooth, root apex, endodontic treatment, open apex, MTA, regenerative endodontics

\section{INTRODUCTION}

When a tooth erupts in the oral cavity the apical foramen undergoes anatomical changes, along with age, while root formation is still incomplete. The root development is completed with apical closure three years after tooth eruption [1]. Injury or trauma before the apical closure interferes with root development. Other cases of open apex are found after pulp necrosis due to caries and periapical lesion with root end resorption. Even hand files, rotary files and lack of control of working length are also factors responsible for an open apex. Endodontic treatment of a non-vital immature tooth remains complicated due to the large open apex $[1,2]$.

\section{OBJECTIVES}

The aim of the study is to investigate various challenging factors affecting the treatment of open root apex, different treatment strategies indicated for open root apex, and to perform comparative analysis of MTA with different materials.

Challenging factors affecting the treatment of open root apex. Dental trauma is considered a multifactorial health

Address for correspondence: Ravinder Nath Bansal, Guru Gobind Singh Medical Hospital, Medical Campus, 151203, Faridkot, India

E-mail: rnbansal@gmail.com

Received: 13.05.2020; accepted: 31.07.2020; first published: 09.09.2020 problem worldwide that frequently requires multidisciplinary treatment planning to improve the quality of life of a patient. An immature root with a necrotic pulp and apical periodontitis presents multiple challenges to successful treatment. These challenges are:

- Susceptibility to fracture. Immature apical formation is a challenging factor as large open apices with thin and divergent dentinal walls are prone to fracture.

- Difficulty in complete disinfection and debridement of the root canal. Open apex poses difficulty in disinfection of the root canal. The infected root canal space cannot be disinfected with the standard root canal protocol using endodontic files aggressively as the coronal diameter of canal is often smaller than apical diameter $[1,3]$.

- Difficulty in obturation. Since there is no closure of the apex, formation of mineralized tissue in the apex becomes imperative for an apical seal in order that obturating material can be adapted 3-dimensionally in the root canal. The main purpose of endodontic treatment is to accomplish obturation of the root canal space completely and prevention of re-infection. Once the microbial phase of the treatment is completed, open apex do not provide an apical stop, thus allowing the root filling material to impinge the periodontal tissues making obturation difficult $[4,5]$. 


\section{TREATMENT STRATEGIES FOR AN OPEN ROOT APEX}

The success of an endodontic treatment depends on whether or not there exist an ideal apical barrier so that apical canal space between periodontium and the root canal system is filled. The endodontic treatment of non-vital immature anterior teeth after trauma presents several complications because of large open apices, necrotic pulp tissue, thin dentinal walls, divergent root walls and frequent periapical lesions. For the treatment of teeth with open apex to be successful it is essential to be acquainted with the compatibility of the material being used, its response physiologically as well as histologically during and after use. For the long term success of endodontic treatment, complete disinfection by means of biomechanical preparation and 3-dimensional obturation of the root canal is required. Definitive success in such a case would require a 'closed apex' which can be achieved via apexification by placing a biololgically-active and biocompatible material that would aid the development of an incompletely developed root apex [6].

\section{COMMONLY EMPLOYED TREATMENT STRATEGIES}

Apexogenesis. Applied in the case of vital teeth apexogenesis (vital pulp treatment) is required to promote continued physiological development; completion of the root end.

Apexification. Indicated in the of permanent tooth presenting non-vital pulp,as well as an open apex where it results in apical repair as a hard tissue seal across an open root apex. According to the American Association of Endodontist's Glossary of endodontic terms, apexification is defined as 'a method of inducing a calcified barrier in a root with an open apex or the continued apical development of an incompletely formed root in teeth with necrotic pulp.' When necrosis of the pulp occurs due to trauma and dental caries, then the treatment of choice should be apexification. Apexification induces apical closure via formation of mineralized tissue (bone, osteodentin or osteocementum or combination of all) in the apical pulp area of a non-vital incompletely formed tooth $[3,4,6]$.

\section{VARIOUS MATERIALS USED FOR APEXIFICATION}

Calcium hydroxide. Calcium hydroxide or its combination with other materials is the most frequently indicated material of choice for apexification. Apexification with calcium hydroxide involves multiple visits lasting for a period of 6 months to 2 years, until the root apex is closed. In one case report [7], Calcium hydroxide and Iodoform paste, i.e. Metapex (Meta Biomed Co. Ltd, South Korea), was placed into the root canals with the help of plastic needles supplied by the manufacturer. After drying the canals with sterile paper points, obturation was performed using a material of choice, e.g. Gutta Percha with a cold lateral condensation technique. Post-obturation radiograph showed an apical calcific barrier on both root tips of affected tooth [7].

Mineral trioxide aggregate (MTA). Mineral Trioxide Aggregate (MTA) shows an ability to seal a root canal system with superior biocompatibility for the repair of root perforations and pulpcapping [8]. It permits vertical compression of sealers and fillers in the rest of the root canal space [6].

MTA is a low soluble material capable of healing as well as sealing root canals. It attains a $\mathrm{pH}$ of 12.5 after setting, which is favourable for its antimicrobial property [3, 9]. In 1993, MTA was introduced by Mohmoud Taorabinejad at Loma Linda University, California, USA [10], followed by approval in 1998 by the US Food and Drug Administration for endodontic applications $[11,12]$. MTA is available as grey (GMTA) and white MTA (WMTA). Scanning electron microscopy (SEM) and electron probe microanalysis characterized the differences between GMTA as well as WMTA, and proved that the major difference between the two depended on the concentrations of $\mathrm{MgO}, \mathrm{FeO}$ and $\mathrm{Al}_{2} \mathrm{O}_{3}$ $[13,14]$. For an hermetic seal to be obtained, a moist cotton pellet over MTA is required as it possess setting expansion. Obturation is performed 72 hours after MTA placement when it achieves a high compressive strength $[15,16,17]$.

MTA on X-ray diffraction (XRD) analysis showed the presence of a completely crystalline material containing tricalcium, dicalcium silicate and bismuth oxide [18, 19], whereas precise quantitative analysis proved it to be composed of tricalcium aluminate and calcium sulphate (in the hemi-hydrate and anhydrite form), in addition to tricalcium, dicalcium silicate [20].

Mechanism of action of MTA. Cells release lymphokines due to its osteoinductive activity for the repair \& regeneration of cementum, which stimulates bio-reminaralisation and the healing of bony defect in the periapical area. MTA induces interleukin (IL) by osteoblasts. Both types of MTA are capable of initiating osteogenic phenotype and promoting the production of osteopontin, osteoridogen, osteonectin, and elevate the level of alkaline phosphates. However, white MTA has a more inferior sealing property than grey due to more leakage (white $-36.4 \%$; grey $-9.1 \%$, after 42 days) $[15$, $21,22,23]$.

Biodentine. Biodentine is a novel calcium silicate-based cement and a bioactive dentin substitute indicated for the repair of root perforation, apexification and retrograde root canal filling. It is available as powder in a capsule, and as a liquid in a pipette. The powder consists of dicalcium silicate, calcium carbonate and tricalcium silicate, which are the main and secondary core materials; other ingredients present are iron oxide shade, zirconium oxide and oxide filler. Zirconium oxide gives radiopacity. The liquid contains calcium chloride as an accelerator and a hydrosoluble polymer as a water reducing agent. Apexification with Biodentine requires significantly less treatment time between the patient's first visit and the final restoration. It has superior sealing ability, is biocompatible, and less cytotoxic in comparison to other materials currently being used in pulpal therapy [4]. When compared with other materials, such as glass ionomer cement and MTA, Biodentin exhibites the least microleakage [24].

Mechanism of action of Biodentin. Biodentin activates pulp progenitor cells leading to odontoblast differentiation and regeneration of dentine in human tooth cultures [25]. It has been found that Biodentin results in a significant increase of TGF- $\beta 1$ secretion from pulp cells, possessing an early mineralization of dental pulp shortly after its application [26]. For treatment to be successful, cleaning and shaping 
of the root canal is required, followed by apical seal with a favourable regenerating material [4].

White Portland Cement (WPC). White Portland Cement (WPC) is almost identical to MTA from the microscopical and macroscopical point of view. Under X-ray diffraction it possess same antimicrobial, physical, chemical and biological properties and with similar outcomes during in vivo and in vitro studies $[27,28,29]$. WPC does not contain bismuth oxide but contains potassium. The arsenic release from both materials is in the range of $0.002-0.007 \mathrm{ppm}$, which is lower than that of drinking water $[30,31]$. In dogs and pig, both materials have shown effective pulpotomies as well as hard tissue formation $[32,33,34,35,36]$.

Composition of White Portland Cement (WPC). WPC has 2 main constituents: tricalcium silicate and dicalcium silicate, as well as other constituents, e.g. $20 \%$ silica, $65 \%$ lime $10 \%$ ferric oxide, aluminium and 5\% other compounds [37].

Modified WPC has been found to seal an open apex. After 3-6 months follow-up, clinical symptoms and peri-apical rarefactions disappeared [38].

\section{REGENERATIVE ENDODONTICS (REVASCULARIZATION/PULPAL REGENERATION)}

Regenerative endodontics (revascularization/pulpal regeneration) is one of several exciting new developments in endodontics [39]. In 2012, the American Association of Endodontists defined regenerative endodontics as a 'biologically-based procedure designed to physiologically replace damaged tooth structures, i.e. dentin and root structures, as well as cells of the pulp-dentin complex' [39].

The regenerative endodontic protocols are:

(a) root canal system disinfection without damaging the endogenous stem cell from apical papilla (SCAP) and other tissues;

(b) provision of a scaffold, which involves laceration of the periapical tissue to induce a blood clot and introduce stem cell activity, followed by placement of an intracanal barrier to prevent microleakage;

(c) an adequacy of coronal seal.

Regenerative endodontics is based on the biological concept of stem cells harmony, scaffold and signalling molecules [5].

In the era of research and innovation, research is a human activity which utilizes intellect to investigate, understand and modify knowledge for the diverse aspects of the world [40, 41]. In search data bases, inventions related to dental surgery, and more particularly to diseased pulp tissue repair, there are specifications describing technologies related to the repair and regeneration of damaged or diseased human pulp tissue. Implementations of the technology described are comprised of removal of diseased pulp tissue from a tooth, followed by disinfection and implantation with collagen matrix coupled with calcium phosphate mineral composite material $[42,43]$. Indications of regenerative endodontics are listed in Table.1

Alternatives to regenerative endodontics are MTA apexification, no treatment and extraction of tooth in the case where a tooth cannot be saved [44].

During the first visit for regenerative endodontics, the tooth is isolated with a rubber dam and preparation for
Table 1. Indications of regenerative endodontics

Regenerative endodontics is indicated:

in young, cooperative patients aged 8-16, immature infected teeth, teeth with minimal periapical pathology and necrotic pulp $[5,44]$

when the patient is not allergic to antibiotics and medicaments used in treatment in cases where pulp space is not required for post/core and final restoration [44].

access is carried out under local anaesthesia. Copious and gentle irrigation of the canal is performed with $1.5 \% \mathrm{NaOCl}$, $20 \mathrm{ml}$ per canal for $5 \mathrm{~min}$. Irrigation is then carried out with saline or EDTA $(20 \mathrm{~mL} / \mathrm{canal}, 5 \mathrm{~min})$, about $1 \mathrm{~mm}$ from the root end, to minimize cytotoxicity to the stem cells apically, and to minimize the extrusion of irrigants periapically [44]. Calcium hydroxide or a low concentration of triple antibiotic paste (TAP) containing Ciprofloxacin: Metronidazole: Minocycline (1-5 mg/ml in the ratio of 1:1:1) is placed in the dried root canal space. It is advisable to seal the pulp chamber with a dentin- bonding agent below CEJ to minimize the risk of stains and tooth discolouration due to the minocycline. Therefore, double antibiotic paste (DAP) without minocycline can be used, or a substitution of minocycline with clindamycin or amoxicillin; cefaclor can be carried out. Temporary restorative material, e.g. Cavit $3-4 \mathrm{~mm}$ in thickness is placed for 1-4 weeks [44].

During the second visit for regenerative endodontics, if infection has persisted, additional treatment with antimicrobial or alternative antimicrobial should be considered. Bleeding is induced into the canal by overinstrumentation using an endo-file, endo-explorer or by rotating a pre-curved K-file, $2 \mathrm{~mm}$ past apically to fill the entire root canal with blood to the level of the cementoenamel junction. Platelet-rich plasma (PRP) or autologous fibrin matrix (AFM) or platelet rich fibrin (PRF) can be used to fill the canal space. Restorative material in a 3-4 mm layer is placed with white MTA as capping material, followed by a 3-4 mm layer of light-curable flowable glass ionomer gently over the white MTA. Biodentine can be used instead of white MTA due to the discolouration effect [44].

Pain, soft tissue swelling, or sinus tract disappears between the first and second visits. At 6, 12 and 24-months intervals, follow-up is performed clinically and radiographically. After 6-12 months of treatment, apical radiolucency is resolved and bony healing is evident. The width of the root walls is increased 12-24 months after treatment, followed by an increase in root length. Pulp vitality test shows a positive response. After the first 2 years, an annual follow-up is recommended [44].

Regenerative endodontics is a relatively simple and practical approach, easily accomplished with currently available instruments and materials. As the root canal is filled with the patient's own blood cells, it minimizes immune rejection and contamination $[45,46]$. In addition to its several advantages, regenerative endodontics also has some limitations (Tab. 2).

Injectable PRF (i-PRF). An ideal alternative treatment for an immature necrotic tooth is the regeneration of tissue resembling pulp, and having the capability to boost normal root development. The action of i-PRF (Injectable plateletrich fibrin) is based on the similar concept of PRF, but it is available in an injectable form. i-PRF has great potential in the field of endodontics. It was first developed in 2014 by introducing modifications in the centrifugation parameters, 
Table 2. Limitations of regenerative endodontics [47-48]

There is potential risk of necrosis, if there is tissue reinfection

In ful-developed permanent teeth it is not easy to achieve this treatment

Causes crown discolouration

Long-term use of antimicrobial agents can lead to development of resistant bacterial strains

There are chances of allergic reaction to intracanal medicament

In the case of older patient, there is unpredictability for the concentration and composition of the progenitor/stem cells entrapped in the fibrin clot, resulting in discrepancies in the results

It is a supplemental treatment to already existing treatment protocols, such as apexogenesis, apexification or partial pulpotomy

i.e.700 rpm for 3-5 min $[49,50]$. It works on the Low Speed Centrifugation Concept (LSSC) of Choukron. This is a flowable, natural blood concentrate with ease of access and flow within the root canal. It coagulates a few minutes after injection. At present the treatment is still in its infancy and needs to be explored with regard to its regenerative efficacy. It contains platelets, leukocytes, stem cells and endothelial cells [49-50]. i-PRF is being studied for its regenerative potential and release of growth factors because of the slower and shorter centrifugation spin. It releases several biomarkers, such as interlukin-1 (IL-1), IL-6, IL-4, tumour necrosis factor alpha (TNF alpha), transforming growth factor $\beta 1$ (TGF $\beta 1$ ), vascular endothelial growth factor (VEGF), platelet derived growth factors (PDG), and insulin-like growth factors (IGFs) which are required for the regeneration of periradicular tissues, especially in open apex cases. i-PRF forms a clot of small size because of its fibrin components which behave as dynamic gel-containing cells and releases additional growth factors, even 10 days after application. This property of i-PRF helps in the regeneration and fast healing of periradicular tissues $[49,50]$.

Platlet rich plasma (PRP). Platlet rich plasma (PRP) is used to increase the speed of soft and hard tissue healing. PRP provokes proliferation of tooth pulp cells and elevates alkaline phosphatase (ALP) activity. The collection of blood sample from children is somewhat problematic. For PRP preparation, the blood samples are collected into $10 \mathrm{~mL}$ tubes containing an acid-citrate-dextrose solution. Citrated blood is centrifuged for $15 \mathrm{~min}$ at 3,000 rpm. The lower red blood cell portion is discarded after the first spin and the supernatant is again centrifuged for $5 \mathrm{~min}$ at 3,000 rpm. The resulting thrombocyte pellet constitutes the PRP $[51,52]$.

\section{COMPARATIVE ANALYSIS OF POPULAR MTA WITH OTHER MATERIAL IN APEXIFICATION}

MTA and Calcium Hydroxide. Calcium Hydroxide has no adverse periapical reaction and is therefore commonly used for apexification. It can be mixed with several materials, e.g. anesthetic solutions, distilled water, camphorated monochlorophenol, saline, and chlorhexidine to promote apical closure [53]. In comparison to calcium hydroxide, MTA is expensive and does not reinforce root canal dentine $[54,55]$. According to a literature review, both materials have been found to be similar in clinical and radiographic trials. MTA showed a significantly shorter treatment time than calcium hydroxide to obtain apical barrier formation, increasing patient compliance and a higher overall success rate $[56,57]$.
MTA and Biodentine. Biodentine is a calcium silicatebased cement having physical and chemical characteristics analogous to certain Portland cement derivatives [4]. It has several advantages over MTA, Glass Ionomer cement (GIC), etc., in the treatment of teeth with open apices [24].The 24-h push-out strength of Biodentine was found to be higher than MTA [58].

MTA and White Portland cement (WPC). MTA is almost 1,000 times more expensive than WPS. WPS available as a cheaper substitute for MTA is thought to be beneficial for developing countries $[37,59]$. In vivo and in vitro studies have shown that both MTA and WPC have comparative bio-compatibility [59]. One study has also demonstrated that MTA and WPC have no cytotoxicity [59], and healing was observed within a short span of 3 months [37].

MTA and Lyophilized collagen sponge apical stop. Due to the high alkalinity of MTA, there exists a risk of necrosis if it comes into direct contact with apical tissue; for instance, after accidental apical over-filling. In such a case, an apical barrier with a lyophilized collagen sponge and MTA cement allows a single visit for root canal filling, in a safe and noninvasive manner. After apical condensation of lyophilized collagen, the presence of apical barrier is confirmed by an endodontic file permitting the safe placement of the MTA apical barrier with approximately $4 \mathrm{~mm}$ thickness. It promotes complete alveolar bone healing in 24 days, with the presence of trabecular bone, a large amount of blood vessels and fibroblasts [60]. Lyophilized collagen is obtained from animal skin (Gelfoam). After placement of the lyophilized collagen sponge in the radicular apical third, healing of the periapical lesion occurs in similar way to that in the alveolar bone socket [60].

MTA and Platelet Rich Fibrin (PRF) membrane. Platelet-rich Fibrin (PRF) is a matrix of platelet and leukocyte cytokines embedded in autologous fibrin and used as an apical membrane [61] (Fig. 1).

A non-surgical treatment in the case of single visit apexification usinga combination of MTA and PRF membrane as a matrix, has proved to be an effective treatment option for

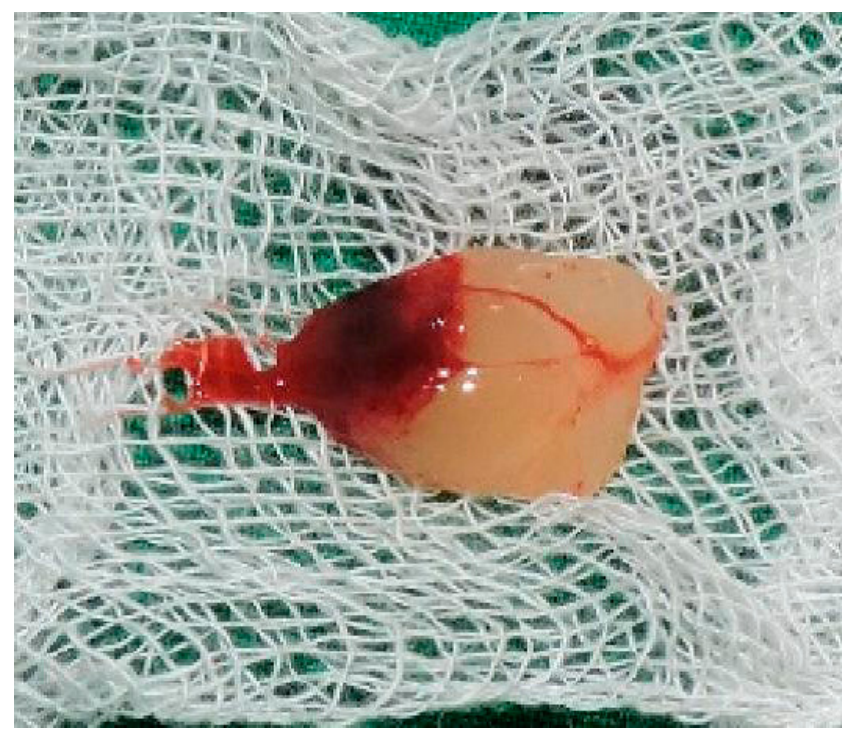

Figure 1. Platelet Rich Fibrin (PRF) 
generating root-end barriers and inducing rapid periapical healing in symptomatic teeth with immature apices, as well as in large periapical lesions. PRF membrane maintains and protects the grafted biomaterial, and fragments itself to serve as biological connectors between bone particles. It facilitates neo-angiogenesis, vascularization and graft survival. It also accelerates the healing of wound edges preventing the extrusion of the material into the periodontal tissues, allowing a favourable response by periodontal tissues [61].

Mechanism of action. It creates healing via platelet cytokines (PDGF, TGF- IGF-1), and the presence of leukocytes, cytokines in the fibrin network self-regulates inflammation, and infection within the grafted material [61]. Different materials used in open apex treatment, their applications, advantages and disadvantages are listed in Table 3.

\section{CONCLUSIONS}

A number of treatment options using several materials have been found but calcium hydroxide is the most widely accepted material (Tab. 3). However, its use is limited due to certain disadvantages. Moreover, due to geographical reasons, patient cannot pay multiple visits over an extended treatment plan, and attrition may also set in. If a child patient moves to another place during the treatment, the dressing will not be changed as needed until the formation of an apical barrier. Multiple clinical visits are even traumatizing for a child patient and appointments are also not easy to remember. Even the integrity of the apical barrier is not certain at the time of final obturation after hard tissue deposition by calcium hydroxide. Thus, there is a stringent need for a reliable single visit apexification.

In the literature, MTA has proved to be better than calcium hydroxide, and found to be most favourable for single-visit apical closure having several clinical applications in surgical

Table 3. Different materials used for open apex treatment with their applications, advantages and disadvantages

\begin{tabular}{|c|c|c|c|c|}
\hline Material & Therapeutic Application/Indications & Advantages & Disadvantages & Ref. \\
\hline Calcium hydroxide & $\begin{array}{l}\text { indicated in necrotic teeth with open apices } \\
\text { stimulates hard tissue deposition at the apex } \\
\text { presence of high calcium concentration } \\
\text { increases the activity of calcium dependent } \\
\text { pyrophosphate } \\
\text { high pH activate alkaline phosphatase activity } \\
\text { needs patient compliance }\end{array}$ & $\begin{array}{l}\text { antibacterial properties } \\
\text { enhanced success rate } \\
\text { easy availability for the clinician } \\
\text { affordability for patients } \\
\text { direct effect on the apical and } \\
\text { periapical soft-tissue }\end{array}$ & $\begin{array}{l}\text { need for multiple visits } \\
\text { long treatment period (6-24 months) } \\
\text { increased chances of reinfection due to loss } \\
\text { of temporary restoration } \\
\text { porous barrier } \\
\text { undermines mechanical strength of dentin }\end{array}$ & {$[6,7]$} \\
\hline Biodentine & $\begin{array}{l}\text { indicated for the repair of root perforations, } \\
\text { apexification } \\
\text { for permanent dentine replacement, } \\
\text { temporary enamel replacement } \\
\text { pulp protection in deep carious lesions } \\
\text { restoration of cervical and/or radicular lesions } \\
\text { direct and indirect pulp capping } \\
\text { pulpotomy, } \\
\text { repair of internal and external resorption }\end{array}$ & $\begin{array}{l}\text { requires significantly less time, } \\
\text { favours regeneration } \\
\text { reduced potential for fracture of } \\
\text { immature teeth with thin roots } \\
\text { user-friendly with shorter setting } \\
\text { time }\end{array}$ & $\begin{array}{l}\text { technique sensitive } \\
\text { Sealing material if extruded periapically } \\
\text { gets resorbed resulting in persistence of } \\
\text { inflammatory process and prevent tissue } \\
\text { repair }\end{array}$ & {$[4,24]$} \\
\hline $\begin{array}{l}\text { White Portland } \\
\text { Cement (WPC) }\end{array}$ & $\begin{array}{l}\text { treatment of teeth with necrotic pulp and } \\
\text { periapical lesion } \\
\text { for single sitting apexification, can be used in } \\
\text { moist environment }\end{array}$ & $\begin{array}{l}\text { as a good apical seal in the wide } \\
\text { open apex of an infected root canal } \\
\text { healing in a short span of } 3 \text { months } \\
\text { no cytotoxic effects } \\
\text { cheaper }\end{array}$ & $\begin{array}{l}\text { lower radio-opacity } \\
\text { arsenic present in the material } \\
\text { highly alkaline } \\
\text { a risk of necrosis exists if there is direct } \\
\text { contact with the apical tissues }\end{array}$ & {$[27-31]$} \\
\hline $\begin{array}{l}\text { Lyophilized collagen } \\
\text { sponge }\end{array}$ & $\begin{array}{l}\text { placement of an apical barrier of lyophilized } \\
\text { collagen sponge with MTA } \\
\text { avoids the risk of root canal contamination } \\
\text { avoids the risk of radicular fracture }\end{array}$ & $\begin{array}{l}\text { easy to handle } \\
\text { biocompatible } \\
\text { absorbable } \\
\text { single visit, } \\
\text { safe, non-invasive procedure } \\
\text { tissue tolerable } \\
\text { promotes healing in } 24 \text { days, } \\
\text { presence of apical barrier confirmed } \\
\text { by endodontic file }\end{array}$ & $\begin{array}{l}\text { its insertion in the apical radicular third } \\
\text { needs specific gutta-percha condenser/ } \\
\text { endodontic file }\end{array}$ & {$[60]$} \\
\hline $\begin{array}{l}\text { Combination of PRF } \\
\text { membrane and MTA }\end{array}$ & $\begin{array}{l}\text { apexification in cases with large periapical } \\
\text { lesions } \\
\text { in symptomatic teeth with immature apices }\end{array}$ & $\begin{array}{l}\text { single visit } \\
\text { nonsurgical procedure }\end{array}$ & $\begin{array}{l}\text { Possible refusal of puncture required for } \\
\text { blood collection by child patient }\end{array}$ & [61] \\
\hline $\begin{array}{l}\text { Regenerative } \\
\text { endodontics }\end{array}$ & $\begin{array}{l}\text { basic concept is to produce new tissues in } \\
\text { place of necrotic pulp }\end{array}$ & $\begin{array}{l}\text { helps in increasing thickness } \\
\text { increses length of root } \\
\text { aids in apical closure of immature } \\
\text { teeth }\end{array}$ & $\begin{array}{l}\text { crown discoloration } \\
\text { resistant bacterial strains } \\
\text { allergic reaction to the intracanal } \\
\text { medication }\end{array}$ & {$[5,44-46]$} \\
\hline $\begin{array}{l}\text { i PRF Injectable } \\
\text { platelet-rich fibrin }\end{array}$ & for an immature necrotic tooth & $\begin{array}{l}\text { easy to prepare } \\
\text { antibacterial effect } \\
\text { minimally invasive approach } \\
\text { reduced healing period }\end{array}$ & $\begin{array}{l}\text { Possible refusal of puncture required for } \\
\text { blood collection }\end{array}$ & [49-50] \\
\hline
\end{tabular}


and non- surgical endodontics. The points in favour of MTA are its single-sitting use, biocompatibility and hermetic apical seal with no micro-leakage. It should therefore be considered as an effective alternative for treating immature teeth with necrotic pulp. On comparing MTA with other materials, it was found that apical barrier formation with MTA was obtained earlier than with calcium hydroxide, thus increasing patient compliance and the quality performance in terms of the time factor. Biodentine showed a higher 24-h push-out strength than MTA, showing better mechanical properties and least microleakage, but is technique sensitive. In India, considering the cost factor in the developing market, White Portland Cement (WPC) is cheaper than MTA for better performance. The high alkalinity of MTA poses a risk of necrosis if it comes into direct contact with apical tissues. In this case, a lyophilized collagen sponge acts as a protective apical barrier against the chemical behaviour of MTA.

Regenerative endodontics is an exciting new development in endodontics indicated in immature infected teeth and teeth with minimal periapical pathology. A non-surgical treatment using a combination of MTA and PRF membrane as a matrix has proved to be an effective treatment option for single visit root-end barrier and periapical healing. Simply expressed, treatment of a tooth with open apex faces multiple challenges. It is not a simple matter to decide which material should be used. The choice of treatment regimen depends on the individual case, experience of the operator, as well as familiarity with handling the various materials available. Patient availability and compliance for follow-up appointments is a most crucial factor to be considered.

\section{Conflict of interest}

The authors have no conflicts of interest to declare.

\section{REFERRENCES}

1. Smyth R, Bob Philpot B. Management of the open apex in endodontics: Scottish Dental magazine. Available from: https://www.sdmag. co.uk/2017/07/25/management-of-the-open-apex-in-endodontics/

2.Das T, Gupta S, Atom J, Lairenlakpam R, Gupta S, Chaudhary A. Endodontic management of blunderbuss canal with open apex and Ellis Class IV fracture using mineral trioxide aggregate and compo-post. Int J Prev Clin Dent Res. 2019; 6: 66-8. Available from: http://www.ijpcdr. org/text.asp?2019/6/3/66/271530

3. Jain P, Rita C, Agarwal RS. Single Visit Apexification Technique for Inducing Root-End Barrier Formation in Apical Closures: Report of Two Cases. P J Sci Res. 2014; 7(1): 40-46.

4. Khetarpal A, Chaudhary S, Talwar S, Verma M. Endodontic management of open apex using Biodentine as a novel apical matrix. Ind J Dent Res. 2014; 25: 513-16. Available from: http://www.ijdr.in/ text.asp?2014/25/4/513/142555

5. Dali M, Rajbanshi L. Regenerative endodontics: Changes, chances, and challenges of revascularization in pediatric dentistry. SRM J Res Dent Sci. 2014; 5: 186-189. Available from: http://www.srmjrds.in/text. asp?2014/5/3/186/138743

6. Fahd A A Karim, Kazi Hossain Mahmud, Asma Sultana, Shirin Sultana Chawdhari, Muktadir Hossain Shaihan Mohamed, Parmina D. Costa. Management of non-vital anterior tooth with open apex by MTA apical plug - A case report. Up Den Col J. 2019; 9(1): 42-45. doi: https://doi. org/10.3329/updcj.v9i1.41206

7. Mathew J, Syriac G, Nair M, Rahul J. Conventional Multi visit Calcium Hydroxide Apexification with Rare Apexogenesis Like Outcome and Novel Single Visit MTA Apexification Followed by Root Reinforcement with Fiber Post: Two Case Reports. Saudi J Oral Dent Res. 2017; 2(2): 43-48. doi: 10.21276/sjodr.2017.2.2.1

8. Saha S, Agrawal V, Srikumar GPV, Sharma V. Single Visit MTA Appexification of a Blunderbuss Canal: A Case Report. Int J Oral Health Med Res. 2016; 3(3): 77-79. ISSN 2395-7387.
9. Economides N, Pantelidou O, Kokkas A, Tziafas D. Short-term periradicuiar tissue response to MTA as a root end filling material. Int Endo J. 2003; 36: 44-8. https://doi.org/10.1046/j.0143-2885. 2003.00611.x.

10. Lee SJ, Monsef M, Torabinejad M. Sealing ability of a mineral trioxide aggregate for repair of lateral root perforations. J Endod. 1993; 19: 541-4.

11. Schwartz RS, Mauger M, Clement DJ, Walker WA. Mineral trioxide aggregate: A new material for endodontics. J Am Dent Assoc. 1999; 130: $967-75$

12. Srinivasan V, Waterhouse $\mathrm{P}$, Whitworth J. Mineral trioxide aggregate in paediatric dentistry. Int J Pediatr Dent. 2009; 19: 34-47.

13. Asgary S, Parirokh M, Egbbal MJ, Brink F. Chemical differences between white and gray mineral trioxide aggregate. J Endod. 2005; 31: 101-3.

14. Macwan C, Deshpande A. Mineral trioxide aggregate (MTA) in dentistry: A review of literature. J Oral Res Rev. 2014; 6: 71-4.

15. Sluyk SR, Moon PC, Hartwell GR. Evaluation of setting properties and retention characteristics of Mineral Trioxide Aggregate when used as a furcation perforation repair material. J Endod. 1998; 24: 768-71.

16. Torabinejad M, Chivian N. Clinical applications of mineral trioxide aggregate. J Endod 1999; 25: 197-205.

17. Schmitt D, Lee J, Bogen G. Multifaceted use of ProRoot MTA root canal repair material. Pediatr Dent. 2001; 23: 326-30.

18. Camilleri J, Montesin FE, Brady K, Sweeney R, Curtis RV, Ford TR. The constitution of mineral trioxide aggregate. Dent Mater. 2005; 21(4): 297-303.

19. Camilleri J, Montesin FE, Di Silvio L, Pitt Ford TR. The chemical constitution and biocompatibility of accelerated Portland cement for endodontic use. Int Endod J. 2005; 38(11): 834-42.

20. Camilleri J. Characterization of hydration products of mineral trioxide aggregate. Int Endod J. 2008; 41(5): 408-17.

21. Holland R, Filho JA, de Souza V, Nery MJ, Bernabe PF, Junior ED. Mineral trioxide aggregate repair of lateralroot perforations. J Endod. 2001; 27: 281-4. https://doi.org/10.1097/00004770-200104000-00011

22. Withersppon DE, Small JC, Regan JD, et al. Retrospective analysis of open apex teeth obturated with mineral trioxide aggregate. J Endod. 2008; 34, 1171-6. https://doi.org/10.1016/j.joen.2008.07.005 pmid:18793914

23. Aminoshariac A, Hart Well GR. Moon PC. Placement of MTA Using 2 different techniques. J Endo. 2003; 29, 679-68. https://doi. org/10.1097/00004770-200310000-00017

24. Kokate SR, Pawar AM. An in vitro comparative stereomicroscopic evaluation of marginal seal between MTA, Glass Inomer Cement and Biodentine as root end filling materials using $1 \%$ methylene blue as tracer. Endod. 2012; 2: 36-42.

25. About I, Laurent P, Tecles O. Bioactivity of Biodentine ${ }^{\mathrm{ma}}$ a CA3SiO5based Dentine Substitute. Oral session. IADR Congress 2010 July, Barcelona, Spain.

26. Laurent P, Camps J, About I. Biodentine (TM) induces TGF-ß1 release from human pulp cells and early dental pulp mineralization. Int End J. 2012; 45: 439-48.

27. Wucherpfenning AC, Green DB. Mineral trioxide VS Portland cement: two biocompatible filling material. J End. 1999; 25: 308 .

28. Camilleri J. Hydration mechanisms of mineral trioxide aggregate. Int End J. 2007; 40: 462-70.

29. Tay FR, Pashley DH, Rueggeberg FA, Loushine RJ, Weller RN. Calcium phosphate phase transformation produced by the interaction of the Portland cement component of white mineral trioxide aggregate with a phosphate-containing fluid. J End. 2007; 33: 1347-51.

30. Duarte MA, De Oliveira Demarchi AC, Yamashita JC, Kuga MC, De Campos Fraga S. Arsenic release provided by MTA and Portland cement. Oral Surg Oral Med Oral Path Oral Rad Endod. 2005; 99: 648-50.

31. Monteiro Bramante C, Demarchi AC, de Moraes IG, Bernadineli N, Garcia RB, Spångberg LS, et al. Presence of arsenic in different types of MTA and white and gray Portland cement. Oral Surg Oral Med Oral Path Oral Rad Endod. 2008; 106: 909-13.

32. De Deus G, Petruccelli V, Gurgel-Filho E, coutinho-Filho T. MTA versus portland cement as repair material for furcal perforation: a laboratory study using a polymicrobial leakage model. Int End J. 2006; 39: 293-8.

33. Holland R, de Souza V, Murata SS, Nery MJ, Bernabé PF, Otoboni Filho JA, et al. Healing prozess of dog dental pulp after pulpotomy and pulp covering with MTA or Portland cement. Braz Dent J. 2001; 12: 109-13.

34. Menezes R, Bramante CM, Letra A, Carvalho VG, Garcia RB. Histologic evaluation of pulpotomies in dog using two types of MTA and regular and white Portland cements as wound dressings. Oral Surg Oral Med Oral Path Oral Rad Endod. 2004; 98: 376-9.

35. Shayegan A, Petein M, Abbeele AV. Beta-tricalzium phosphate, white MTA, white Portland cement, ferric sulfate and formocresol used as 
pulpotomy agents in primary pig teeth. Oral Surg Oral Med Oral Path Oral Rad Endod. 2008; 105: 536-42.

36. Shayegan A, Petein M, Abbeele AV. The use of beta-tricalcium phosphate, white MTA, white Portland cement and calcium hydroxide for direct pulp capping of primary pig teeth. Dent Traum. 2009; 25: 413-9.

37. Bhadoria N. Case Report on Apexification with Portland Cement in Children. Int J Oral Health Med Res. 2016; 3(3): 67-69. ISSN 2395-7387.

38. Chakraborty A, Dey B, Dhar R, Sardar P. Healing of apical rarefaction of three nonvital open apex anterior teeth using a white portland cement apical plug. Contemp Clin Dent 2012; 3(2): 177-81. Available from: http://www.contempclindent.org/text.asp?2012/3/6/177/101101

39. American Association of Endodontists Glossary of Endodontic Terms. $8^{\text {th }}$ ed. Chicago: 2012.

40. Gupta S, Bansal RN, Sodhi SPS, Brar GK, Bansal R. Patent: A Journey From Idea To Patent. Inn Int J Sci. 2018; 5(6): 5-11. ISSN 2349-7041.

41. Gupta S, Bansal RN, Bansal R, Sodhi SP, Brar GK. Physician's Participation in Clinical Research - a questionnaire study. J Pre Clin Clin Res. 2019; 13 (2): 57-60. doi: https://doi.org/10.26444/jpccr/108899

42. Root canal for tissue in-growth. https://patents.google.com/patent/ US20140272803A1/en?q=.+Root+canal+tissue+in-growth\&oq=.+Roo $\mathrm{t}+$ canal+for+tissue+in-growth. (access: 2020.05.14)

43. Sealbio: a novel non-obturation regenerative technique of endodontic treatment. https://patents.google.com/patent/AU2010355508B2/ en?q=novel+non-obturation+regenerative+technique+endodontic+tr eatment\&oq=a+novel + non-obturation+regenerative + technique + of + endodontic+treatment (access 14-5-2020).

44. AAE Clinical Considerations for a Regenerative Procedure Revised4/1/2018: https://f3f142zs0k2w1kg84k5p9i1o-wpengine. netdna-ssl.com/specialty/wpcontent/uploads/sites/2/2018/06/ ConsiderationsForRegEndo_AsOfApril2018.pdf

45. Murray PE, Garcia-Godoy F, Hargreaves KM. Regenerative endodontics: A review of current status and a call for action. J Endod. 2007; 33:377-90.

46. Banchs F, Trope M. Revascularization of immature permanent teeth with apical periodontitis: New treatment protocol? J Endod. 2004; 30: 196-200.

47. Garcia-Godoy F, Murray PE. Recommendations for using regenerative endodontic procedures in permanent immature traumatized teeth. Dent Traumatol. 2012; 28: 33-41.

48. Sakthi S, Bharadwaj SL. Pulp revascularisation in pediatric dentistry. J Int Dent. 2012; 1: 34-6.

49. Surender LR, Habeeb, A. A novel combination of injectable plasma rich fibrin and biodentine for the endodontic management of a tooth with an open apex and periapical lesion - a case report. Int J Sci Res. 2017; 6(6): 43-44.
50. Miron R, Choukroun J, Ghanaati S. Controversies related to scientific report describing g-forces from studies on platelet-rich fibrin: Necessity for standardization of relative centrifugal force values. Int J Growth Factors Stem Cells Dent. 2018; 1:80-9. doi: 10.4103/GFSC.GFSC_23_18

51. Güven Polat G, Yildırım C, Akgün OM, Altun C, Dinçer D, Ozkan CK. The use of platelet rich plasma in the treatment of immature tooth with periapical lesion: a case report. Restor Dent Endod. 2014; 39(3): 230-234. doi:10.5395/rde.2014.39.3.230

52. Gupta S. True pain of false healing -various treatment modalities (a research perspective). J Ayur Hol Med. 2018; 6(I): 38-50. ISSN-23211563.

53. Lin JC, Lu JX, Zeng Q, Zhao W, Li WQ, Ling JQ. Comparison of mineral trioxide aggregate and calcium hydroxide for apexification of immature permanent teeth: A systematic review and meta-analysis. J Formosan Med Ass. 2016; 115(7): 523-530. doi: 10.1016/j.jfma.2016.01.010

54. Utneja S, Nawal RR, Talwar S, Verma M. Current perspectives of bio-ceramic technology in endodontics: calcium enriched mixture cement - review of its composition, properties and applications. Rest Dent End. 2015: 40; 1-13.

55. Parirokh M, Torabinejad M. Mineral trioxide aggregate: a comprehensive literature review-Part III: Clinical applications, drawbacks, and mechanism of action. J Endod. 2010; 36: 400-413.

56. Hargreaves KM, Diogenes A, Teixeira FB. Treatment options: biological basis of regenerative endodontic procedures. Pediatr Dent. 2013; 35: 129-140.

57. Shabahang S. Treatment options: apexogenesis and apexification. J Endod. 2103; 39: 26-29.

58. Aggarwal V, Singla M, Miglani S, Kohli S. Comparative evaluation of push-out bond strength of ProRoot MTA, Biodentine, and MTA Plus in furcation perforation repair. J Conserv Dent. 2013; 16: 462-5.

59. Saidon J, He J, Zhu Q, Safavi K, Spångberg LS. Cell and tissue reactions to mineral trioxide aggregate and Portland cement. Oral Surg Oral Med Oral Pathol Oral Radiol Endod. 2003; 95: 483-9.

60. Graziele Magro M, Carlos Kuga M, Adad Ricci W, Cristina Keine K, Rodrigues Tonetto M, Linares Lima S, et al. Endodontic Management of Open Apex Teeth Using Lyophilized Collagen Sponge and MTA Cement: Report of Two Cases. Iran Endod J. 2017; 12(2): 248-252. doi: 10.22037/iej.2017.48

61. Khetarpal A, Chaudhry S, Talwar S, Verma M. Endodontic management of open apex using MTA and platelet - rich fibrin membrane barrier: A newer matrix concept. J Clin Exp Dent. 2013; 5(5) :e291-e294. doi: $10.4317 /$ jced.51178 